The only objection to such a procedure might be its cost. Distribution of voting rights in the parent's stock to minority shareholders of the subsidiary in proportion to their interest in that corporation would involve substantially the same administrative costs as would the holding of a normal election by the subsidiary with the parent excluded. While expense may be good reason to refrain from routine use of the "pass through" technique, it should not deter its employment when control of the parent corporation might thereby be altered.

mon stock of the company held by their savings and profit-sharing pension fund. Shares held by the fund were assigned to individual employee accounts in accordance with the interest of each employee in the fund. The employees are now furnished with proxy statements prior to elections. They submit their votes to an accounting firm which tabulates the results and furnishes voting instructions to the trustees. In this manner, voting rights are accorded to the beneficial owners of this large block of stock and the secrecy of the choice of individual employees is maintained. See also note 4 supra.

\title{
RETROACTIVE DETERMINATION UNDER 18 U.S.C. § 4245 OF A PRISONER'S INCOMPETENCY TO STAND TRIAL
}

In 1949, Congress added four new sections to chapter 313 of title 18, U.S.C., which deals with mentally defective persons accused or convicted of federal crimes. ${ }^{1}$ In adding section 4245 , Congress provided a procedure for vacating a sentence on the ground of mental incompetency at the time of the trial. The section requires that the district court in which the prisoner was convicted hold a hearing:

Whenever the Director of the Bureau of Prisons shall certify that ... [the prisoner] has been examined by the board of examiners referred to in . . . section 4241 and that there is probable cause to believe that ... [he] was mentally incompetent at the time of his trial, provided the issue of mental competency was not raised and determined before or during said trial....2

1 Chapter 313 presently includes sections $4241-48$. Sections $4241-43$ were enacted into positive law by the Act of June $25,1948,62$ Stat. 855 , which included all of Title 18 . All three were re-enactments, with minor changes, of the provisions of a 1930 act, 46 Stat. 272. Sections $4244-48$ were added in 1949, 63 Stat. 686 (1949). The House report explains the addition of these sections:

"Existing Federal statutes prescribe no procedure whatever for determination of an accused person's mental competence to stand trial and there are but few judicial decisions on the question. Consequently, the courts have dealt with suspected cases in various ways as their judgment of the particular case dictated. The importance of uniform treatment is thus made apparent. ... The bill is the result of prolonged, patient, and painstaking study and reflection by a constituted committee of judges ... and representatives of the Attorney General. Its early enactment would be of substantial assistance in clarifying a constantly recurring and vexatious problem." H. R. REP. No. 1309, 81st Cong., 1st Sess. 1-2 (1949).

$2 \S 4245$. Mental incompetency undisclosed at trial.

"Whenever the Director of the Bureau of Prisons shall certify that a person convicted of an offense against the United States has been examined by the board of examiners referred 
Each federal prison has a board of examiners authorized by section 4241 . These boards were established in 1930 to "examine any inmate of the institution alleged to be insane or of unsound mind or otherwise defective and report their findings and the facts on which they are based to the Attorney General."3 The Attorney General is then authorized by section 4241 to order that the prisoner be hospitalized. The legislative history of section 4245 indicates that Congress intended that the board's role in the procedure for vacating sentences should be no more than a collateral consequence of the examination held pursuant to section 4241.4 It would appear that the new section was enacted to protect the rights of prisoners whose convictions were improper but whose rights would not otherwise be asserted. Before the enactment of section 4245 , most of these prisoners could have been discovered in examinations pursuant to section 4241 ; but the prison boards had no formal means of communicating to a court that there was cause to believe that the prisoners prob-

to in title 18, United States Code, section 4241 and that there is probable cause to believe that such person was mentally incompetent at the time of his trial, provided the issue of mental competency was not raised and determined before or during said trial, the Attorney General shall transmit the report of the board of examiners and the certificate of the Director of the Bureau of Prisons to the clerk of the district court wherein the conviction was had. Whereupon the court shall hold a hearing to determine the mental competency of the accused in accordance with the provisions of section 4244 above, and with all the powers therein granted. In such hearing the certificate of the Director of the Bureau of Prisons shall be prima facie evidence of the facts and conclusions certified therein. If the court shall find that the accused was mentally incompetent at the time of his trial, the court shall vacate the judgment of conviction and grant a new trial."

3 § 4241. Examination and transfer to hospital.

"A board of examiners for each Federal penal and correctional institution shall consist of (1) a medical officer appointed by the warden or superintendent of the institution; (2) a medical officer appointed by the Attorney General; and (3) a competent expert in mental diseases appointed by the Surgeon General of the United States Public Health Service.

"Such board shall examine any inmate of the institution alleged to be insane or of unsound mind or otherwise defective and report their findings and the facts on which they are based to the Attorney General.

"The Attorney General, upon receiving such report may direct the warden or superintendent or other official having custody of the prisoner to cause such prisoner to be removed to the United States hospital for defective delinquents or to any other institution authorized by law to receive insane persons charged with or convicted of offenses against the United States, there to be kept until, in the judgment of the superintendent of said hospital, the prisoner shall be restored to sanity or health or until the maximum sentence, without deduction for good time or commutation of sentence, shall have been served."

${ }^{4}$ A statement of the Director of the Bureau of Prisons is set out in the House report. It was his understanding that section 4245 "provides for a hearing and authorizes a new trial for any person who, during service of sentence, is certified by prison officials to be of unsound mind and that such condition probably existed either at the time of commission of the offense or time of trial. Based upon past experience, the percentage of convicts in the first classification, is large enough to justify the belief that mental disturbances of a psychotic nature existed at the time of the trial." H. R. REP. No. 1309, supra note 1, at 2-3.

Judge Bazelon emphasizes this legislative history in his opinion in Fooks v. United States, 245 F.2d 629, 638 (D.C. Cir. 1957). 
ably had been convicted improperly. Section 4245 apparently was intended to provide a formal channel of communication.

Section 4245 probably does provide an effective channel of communication when the question of past competency would not have been raised but for an examination pursuant to section 4241. However, some courts have gone further and assumed that section 4245 provides a procedure for a prisoner who is actively seeking to petition a court for relief. The procedural difficulties arising in the cases in which this assumption has been made indicate that the channel of communication provided by Congress is not adequate if the section is interpreted to apply to prisoners actively seeking relief. The cases discussed in this comment will illustrate these procedural difficulties. Since conflicting interpretations of the procedure authorized by the section have not been clearly set out by the courts, it will be helpful to outline several possible interpretations of section 4245 before considering the cases themselves.

Under the interpretation supported by the legislative history no prisoner could petition pursuant to section 4245 for an examination concerning his past competence to stand trial. 5 This is probably the most practical interpretation since it avoids the problems of administrative discretion that would arise if the board should refuse to grant an examination or if the Director should refuse to certify "probable cause."' A section intended to apply to prisoners actively seeking relief should describe the procedure that the prisoner is to follow in petitioning the board. It should also state the consequences of denial of relief by the Director. Section 4245 does none of these; it merely provides a procedure for the Director to follow after he has found probable cause. ${ }^{7}$

If it is assumed that prisoners may actively petition for relief pursuant to section 4245, then the question arises to what extent this right to petition is limited to certain prisoners by the phrase "examined by the board of examiners referred to in ... section 4241." If the phrase means "examined pursuant to section 4241 ," then the right to petition is limited to prisoners who have been found mentally ill pursuant to section $4241 .{ }^{8}$ If the phrase means only that "the

5 This interpretation is supported by the legislative history in that the role of the prison officials was there emphasized. There is nothing in the report indicating that a prisoner's right to petition was considered. H. R. REP. No. 1309, supra note 1, passim.

6 Under section 4245 the certificate of probable cause "shall be prima facie evidence of the facts and conclusions certified therein." If prisoners are allowed to petition under section 4245 and relief is denied by the prison officials, the question arises whether the denial constitutes "prima facie evidence" sufficient to deny a hearing pursuant to section 2255 of title 28 . See text infra at note 20.

7 The section begins with the Director's first step in his procedure: "Whenever the Director . . shall certify. ..." See text of statute supra at note 2 .

8 This interpretation is supported by the legislative history only to the extent that the Director's statement referred to prisoners found "to be of unsound mind." See note 4 supra. 
examining board is referred to in section 4241 ," then any prisoner may petition for relief pursuant to section 4245.9

The primary function of the prison board of examiners is to determine the present state of a prisoner's mental health. ${ }^{10}$ Evidence as to the prisoner's past should be important to the board only to the extent that it aids in the determination of his present mental condition. The board should not be required to make a retroactive determination based only on evidence concerning the prisoner's past mental condition. This information is equally available to a court-appointed examining board.11

If prisoners are allowed to petition for relief under section 4245 without a prior section 4241 finding of present mental illness, the operation of section 4245 would depend upon section 4241 only in that the examining board is authorized by the earlier section. Under this interpretation, the purpose for which the prison boards were created in $1930^{12}$ would not limit their role under section 4245 .

9 It might be argued that there is an intermediate interpretation which would require that a prisoner be examined pursuant to section 4241 but not that he be found mentally ill. The words of section 4245 support this interpretation. (Under section 4245 the Director certifies that the prisoner has been "examined" by the board; he does not certify that he has been found mentally ill.) However, it is difficult to support this intermediate interpretation as clearly distinct from the interpretation which allows prisoners to petition regardless of whether a section 4241 examination has been held. A prisoner who had been denied a 4245 examination on the ground that a 4241 examination is a necessary condition could then petition for a 4241 examination. This examination would have to be granted, thus satisfying the condition because section 4241 states that the board "shall examine any ... [prisoner] alleged to be insane or of unsound mind or otherwise defective." It seems unreasonable for a court to hold that these words do not grant a right to petition while at the same time holding that such a right can be inferred from the words of section 4245 , which describes only the procedure that the Director is to follow.

There is a practical argument for limiting the right to petition to prisoners who have been found mentally ill under section 4241 . The question of a prisoner's right to petition for a section 4241 examination has never been directly raised. It has however been held that courts may not interfere with procedures taken pursuant to section 4241 . Rosheisen v. Steele, 193 F.2d 273 (8th Cir. 1951) (a prisoner, who had been transferred to a mental hospital under section 4241 , asserted his sanity in order to get the benefit of a deduction for "good time"-a deduction which is denied prisoners who are transferred under section 4241).

Although the rule against court interference with section 4241 proceedings seems to support the intermediate interpretation, it, in fact, argues against the intermediate case in that its general rule of the autonomy of prison officials should apply equally to section 4245 . Thus, if the analysis is pursued to its logical conclusion, prisoners would not be able to petition for relief under either section. If, however, they are allowed to petition under section 4241 , they should be able to do so under section 4245 .

It is difficult to distinguish these interpretations on the basis of the legislative history because there is no indication that prisoner initiation was intended in any case.

10 See 28 U.S.C. $\$ 4241$, set out in note 3 supra. The original establishment of the boards in 1930, 46 Stat. 272, was part of "An Act to establish a hospital for defective delinquents." 46 Stat. 270 (1930).

11 Such a board could be appointed, at the discretion of the court, in a proceeding pursuant to section 2255 of title 28 . See text at notes 14 \& 15 infra.

12 See note 10 supra. 
In the cases discussed in this comment, the courts have assumed that a prisoner may petition pursuant to section 4245 . There has been no complete discussion of the conflicting interpretations which arise if this assumption is made. There is a possible explanation for the lack of judicial discussion of this aspect of the interpretation of section 4245: the question has so far arisen only indirectly in cases where relief has been sought under section 2255 of title 28 U.S.C. Section 2255 provides a general remedy for vacating improper sentences without resort to habeas corpus. 13 One of the particular grounds for relief is the post-conviction allegation of incompetency at the time of the trial.14

Two cases which seem to illustrate no more than questionable use of precedent also illustrate the type of confusion that has resulted when an assumption concerning the operation of section 4245 is a factor in the disposition of a petition under section 2255. In Hoskins v. United States 15 the circuit court affirmed the denial of a motion to vacate which was based on the allegation that the prisoner had been mentally incompetent at the time of his trial. The per curiam disposition stated that the district court "lacked jurisdiction to hold the hearing sought . . . under section 4245 ... where there was no certificate by the Director ... certifying that there is probable cause...."16 It is not clear whether the petitioner or the court characterized the petition as "under section 4245." Since there was no Director's certificate, the court should have treated the motion to vacate as a motion pursuant to section 2255.17

The Hoskins opinion refers without discussion to Cason v. United States. 18 In Cason the petition was explicitly under section 2255 . The prisoner's sole allegation was that, as a matter of law, a plea of guilty may not be accepted

13 According to the reviser's note in the United States Code (28 U.S.C. $\$ 2255$ (1958)):

"This section restates, clarifies and simplifies the procedure in the nature of the ancient writ of error coram nobis. It provides an expeditious remedy for correcting erroneous sentences without resort to habeas corpus."

The motion under 2255 is similar to coram nobis and to the section 4245 procedure in that the potential hearing is before the court which sentenced the prisoner.

14 Bishop v. United States, 223 F.2d 582 (D.C. Cir. 1955). The circuit court denied a motion under section 2255 . The Supreme Court vacated the judgment and remanded to the district court for a hearing on the competency of the prisoner at the time of his trial. 350 U.S. 961 (1956). Subsequent cases have limited Bishop to the narrow holding that relief is available under section 2255 only if there has been a history of insanity prior to the trial. See, e.g., Bistram v. United States, 180 F. Supp. 501 (D.N. Dak. 1960).

15251 F.2d 51 (6th Cir. 1957).

16 Ibid.

17 In United States v. Mancuso, 152 F. Supp. 355, 359 (W.D. La. 1957), the court, in granting relief under section 2255 stated:

"Here the Director of the Bureau of Prisons did not certify that movant had been examined by the board of examiners referred to in 18 U.S.C. 4241 . Hence the provisions of 4245 properly may not be invoked by movant. However, he clearly was entitled to seek relief under the provisions of 28 U.S.C. 2255 and the matter is treated as if such an application had been made."

18220 F.2d 510 (4th Cir. 1955), cert. denied 349, U.S. 966 (1955). 
unless inquiry is made concerning the defendant's mental competency. That contention clearly cannot be supported since it would put the burden on the trial court to make a finding concerning competency even if the question were not raised by counsel or by the suspect behavior of the defendant. Thus the denial of a hearing pursuant to section 2255 was proper since that section provides: "Unless the motion and the files and records of the case conclusively show that the prisoner is entitled to no relief, the court shall ... grant a prompt hearing. . . ."19 After fully supporting its denjal of the section 2255 hearing, the court in Cason concluded by stating, in dictum, that a hearing would be granted if a certificate were filed under section 4245 . The lack of the certificate had nothing to do with the denial of the hearing under section 2255, but the Hoskins court seemed to rely on this unnecessary reference to section 4245 as support for its apparent holding that a 4245 certificate is necessary to give the court jurisdiction whenever the prisoner alleges his past incompetency to stand trial.

Thus in Hoskins there was no support for the court's implicit assumption that all motions to vacate claiming incompetency at the time of the trial must be treated as section 4245 motions. Some courts, however, have held explicitly that relief is not available under section 2255 because section 4245 provides an exclusive remedy. In United States $v$. Meadows ${ }^{20}$ the prisoner contended that he had been found mentally incompetent in another judicial hearing. Thus the records of the case did not "conclusively show that the prisoner is entitled to no relief." However, the court refused to grant a hearing under section 2255 because the prisoner had "misconceived the procedure he should follow in raising the question of his mental competency" to stand trial. ${ }^{21}$ In outlining the procedure that the prisoner should have followed, the court assumed that the prisoner could petition for an examination pursuant to section 4245 .

Gordon v. United States 22 is a more recent case holding that section 4245 precludes relief under section 2255 on the ground of incompetency to stand trial. The Gordon opinion does not discuss the point as clearly as Meadows ${ }^{23}$ but the facts of the Gordon case suggest an important distinction. Unlike Meadows, Gordon had been found mentally ill in a 4241 examination. Therefore, it would have been possible to apply to the Gordon case the interpretation of sec-

1928 U.S.C. $\$ 2255$ (1958).

20140 F. Supp. 184 (W.D. Mich. 1955). The court of appeals adopted the opinion of the district court and reasserted that the prisoner may apply to the Director under section 4245 . 235 F.2d 312 (6th Cir. 1956).

$21140 \mathrm{~F}$. Supp. at 188.

22250 F.2d 676 (10th Cir. 1957).

${ }^{23}$ All that the Gordon court said on this point was: "The language of the section is too clear to leave any doubt that the only remedy such a one has is the remedy provided for in Section 4245. All the cases so hold and citation of authority is deemed unnecessary." 250 F.2d at 678 . 
tion 4245 which allows the prisoner to petition only if he has been found mentally ill pursuant to section 4241. Under this restrictive interpretation, it is difficult to accept the broad rule of the Gordon case that section 4245 provides exclusive relief. ${ }^{24}$ The opinion in Gordon lays down the broad rule without discussing any justification other than the words of the statute. Only the facts of the case suggest that the findings of a section 4241 examination should be available to a court attempting to make a determination of past competency to stand trial.

The suggestion which is implied in the particular facts of the Gordon case is made explicitly in Krupnick v. United States. ${ }^{25}$ The petitioner sought to have his sentence vacated under section 2255 on the ground that the trial court had improperly refused to grant him a competency hearing at the time of his trial. The circuit court reversed the denial of the petition and ordered a nunc pro tunc determination of the petitioner's competence to stand trial. In ordering this determination the circuit court said:

In initial approach to the problem, the court may desire to have the government's psychiatrists, by whom appellant is now being treated, furnish it with a certificate under . . . section 4245, as to whether or not "there is probable cause to believe that such person was mentally incompetent at the time of his trial."26

Under none of the suggested interpretations does section 4245 provide clearly for a certificate of "no probable cause." The circuit court's assumption that such a certificate may be requested by a district court illustrates two important points. First, that section 4245 has been read as authorizing a district court to order examinations which are a part of prison administration. Second, that the assumption that a certificate of "no probable cause" may be requested is based on the courts' view that they should have the benefit of relevant findings made by prison officials.

Section 4245 does not clearly set out a procedure to assure that the relevant findings of prison officials are communicated to courts. The failure to provide for a certificate of "no probable cause" has particularly important consequences since the board's finding of "no probable cause" must be transmitted to the courts informally or by negative implication. In Bistram v. United States 27 the court assumed from the absence of a certificate that there was no probable cause. ${ }^{28}$ However, the absence of a 4245 certificate after a 4241 ex-

24 A strong argument can be made that the holding of a 4241 examination should never limit 2255 relief when the question is one of incompetency to stand trial, since 2255 relief can be granted when the incompetency is clearly temporary. See, e.g., Coates v. United States, 273 F.2d 514 (D.C. Cir. 1959); Pledgor v. United States, 272 F.2d 69 (4th Cir. 1959) (incapacity due to influence of narcotics).

25 264 F.2d 213 (8th Cir. 1959). It is not clear whether Krupnick had been found mentally ill. He was "under diagnosis as to his mental competency." Id. at 218.

26 Id. at 218.

27180 F. Supp. 501 (D.N. Dak. 1960).

28 "This court ordered, on September 16, 1959, that ultimate disposition of petitioner's 
amination does not necessarily imply a conclusion of the board or the Director that there is no probable cause. Even if it is unlikely that a court will deny a hearing under section 2255 relying solely on the negative implication resulting from the absence of a 4245 certificate, 29 the channels of communication should be made more certain.

The uncertainty arising from the lack of adequate channels of communication is further illustrated by Seidner v. United States. 30 There the district court had denied two petitions without a hearing, holding that neither motion alleged a ground upon which relief could be granted. The circuit court appointed an amicus curiae after learning that the prisoner was incarcerated in a mental institution run by the Bureau of Prisons. The amicus raised for the first time the question of the prisoner's competence at the time of his trial. The circuit court ordered the Director to show cause why he had not invoked section 4245. The Director stated that he had examined the report of the board and found no probable cause. The court discharged the order, but decided to allow a judicial hearing despite the Director's indication that there was no probable cause. ${ }^{31}$ The necessity for ordering the Director to show cause why action was not taken under section 4245 indicates the weakness of a procedure which provides for a finding of no probable cause only as an inference from the cir-

motion be reserved pending the filing with this Court within ninety (90) days of that date, by the Attorney General of the United States, the report of the Board of Examiners prepared pursuant to Title 18 U.S.C.A. $\$ 4241$, and the certificate of probable cause, if indicated, by the Director of the Bureau of Prisons as contemplated by Title 18 U.S.C.A. $\S 4245$. The Attorney General has not filed a report of the Board of Examiners prepared pursuant to Sec. 4241 nor a certificate of probable cause as contemplated by Sec. 4245 . From this the Court can only conclude that the petitioner's mental condition did not and does not warrant that any action be taken pursuant to either of the above cited Sections." Id. at 503-04. (Emphasis added.)

${ }^{29}$ For example, the district court's conclusion in Bistram (see note 28 supra) did not depend upon the negative implication from the lack of a 4245 certificate. The opinion begins:

"The matter now before the Court illustrates the constant and vexing problems arising out of the abuse of 28 U.S.C.A. $\$ 2255$, by criminals lawfully imprisoned who, by repeated and successive motions brought under that Section, impose an unnecessarily onerous burden upon an aiready overburdened federal judiciary." Id. at 502.

30260 F.2d 732 (D.C. Cir. 1958).

${ }^{31}$ In a footnote to his concurring opinion, Judge Bazelon suggested a possible reason why the Director had refused to certify probable cause. He quoted from the report of the Classification Committee of the Medical Center to which the prisoner had been transferred pursuant to section 4241 :

"The Classification Committee considered the possibility of referring subject [appellant]' to the Board of Examiners for consideration of processing under Section 4245; however, since it has been nine months since his trial and sentence, the Committee questioned the wisdom of referring this case back to the court." Id. at 735 n.2. (Emphasis by the court.) The Director may have had other reasons for refusing to certify; but it is clear that the Classification Committee's report, which confused problems of medical diagnosis with the prisoner's legal rights, did not, in the court's view, constitute a sufficient basis for his decision. 
cumstances. In this case, the court did not accept the Director's decision, but it did not criticize his failure to act.

In Clatterbuck v. United States 32 the judicial attitude toward the prison authorities was more disapproving. After asserting that the legislation on mental defectives had not been working as expected, Judge Washington commented: "This court has on an earlier occasion in Clatterbuck's history, as Judge Bazelon points out, called the attention of the authorities to the provisions of section 4241. It may not be out of order to remind them of it once again." 33 Since the section 4245 examination is directly related to the work of the courts, it can be argued that it is proper for courts to order such an examination. However, judicial comment concerning the failure to hold a 4241 examination seems much less desirable.

It seems clear, from the words of the section and from the legislative history, that section 4245 was not intended to apply to prisoners actively seeking relief. However, the courts which have assumed the broader application have a basis for this assumption. It seems sensible that the prison board should communicate its findings and recommendations to the courts in any case where these findings are relevant to the determination of past competence to stand trial. It should make no difference that, in some cases, the prisoner is initiating the section 4245 proceeding. However, legislative change is necessary for a clear statement of the procedure to be followed by the prisoner. Any suggestions for legislative change must take into account an important distinction between section 4241 and section 4245 . Section 4241 has primarily a medical purpose of providing proper care for mentally ill prisoners; the section 4245 procedure leads to a legal conclusion concerning competency to stand trial. Any new channels of communication must include safeguards so that the medical emphasis in the examination and report will not distort the legal conclusion. ${ }^{34}$

32266 F.2d 893 (D.C. Cir. 1958).

33 Id. at 900 .

34 See, e.g., note 31 supra.

\section{CONTROL OF THE UNAUTHORIZED PRACTICE OF LAW: SCOPE OF INHERENT JUDICIAL POWER}

Many state supreme courts, relying upon the separation of powers clause of the state constitution, have asserted a broad power to regulate the practice of law. ${ }^{1}$ Some courts have claimed that the power is exclusive and that,

1 The Supreme Court of Oklahoma in In re Bledsoe, 186 Okla. 264, 97 P.2d 556, 557 (1939), explicitly acknowledged that the source of judicial power in this area was the general separation of powers clause. "There is no provision of the Constitution which specifically fixes the authority for determining the qualifications for admission to the bar in either the legislative or the judicial branch of government. The only applicable 